\title{
Aridity and overgrazing decrease soil carbon storage by decreasing grassland plant diversity
}

\author{
Jushan Liu ${ }^{1}$, Forest Isbell ${ }^{2}$, Quanhui $\mathrm{Ma}^{1}$, Ying Chen ${ }^{1}$, Fu Xing ${ }^{1}$, Wei Sun ${ }^{1}$, Ling Wang ${ }^{1}$, \\ Jian $\mathrm{Li}^{1}$, Yunbo Wang ${ }^{1}$, Fujiang $\mathrm{Hou}^{3}$, Xiaoping Xin ${ }^{4}$, Zhibiao $\mathrm{Nan}^{3}$, Nico Eisenhauer ${ }^{5,6}$, \\ and Deli Wang ${ }^{1}$ \\ ${ }^{1}$ Northeast Normal University \\ ${ }^{2}$ University of Minnesota Twin Cities \\ ${ }^{3}$ Lanzhou University \\ ${ }^{4}$ the Chinese Academy of Agricultural Sciences \\ ${ }^{5}$ German Institute for Integrative Biodiversity Research (iDiv) Halle-Jena-Leipzig \\ ${ }^{6}$ University of Leipzig
}

September 11, 2020

\begin{abstract}
Climate and land-use change are some of the most profound threats to the biodiversity and functioning of the Earth's ecosystems, yet potential synergistic effects remain unclear. Here we examined how aridity and land-use (overgrazing and haying) affect aboveground biomass and soil organic carbon (SOC) through changes in plant species richness across 716 grassland sites in northern China. We found that aridity and grazing reduced aboveground biomass and SOC through decreasing plant species richness. Notably, we observed strong negative synergistic effects of aridity and grazing, suggesting that soil carbon storage was particularly threatened by grazing in arid environments. By contrast, haying reduced aboveground biomass and had no significant effect on SOC, although it increased plant species richness. Together, the results demonstrate that climate change and overgrazing mainly threaten soil carbon storage via their detrimental effects on plant diversity, and the detrimental overgrazing effects are particularly strong under arid conditions.
\end{abstract}

\section{Introduction}

Earth's ecosystems have been severely affected by anthropogenically driven environmental change (Barnosky et al. 2012), causing dramatic biodiversity loss (Díaz et al. 2019) and, consequently, threatening their capacity to provide ecosystem functioning and services (Cardinale et al. 2012; Brose \& Hillebrand 2016; Díaz et al. 2019). Grasslands are a globally important biome that comprises approximately $22 \%$ of the Earth's icefree land (White et al.2000), and provides an important contribution to global food supply and security (O'Mara 2012). Grasslands are the most endangered terrestrial ecosystem type due to overexploitation by rapidly increasing human population and consumption (Millenium Ecosystem Assessment 2005), and are more vulnerable to environmental change than some other ecosystems (Hoekstra et al. 2005). Therefore, understanding how grasslands respond to environmental change and land-use is extremely important for global sustainability. However, the combined effects of climate change and land-use on biodiversity and ecosystem functioning are still poorly understood (Siebert et al. 2019).

Biodiversity has been increasingly recognized as a major determinant of ecosystem dynamics and functioning (Tilman et al. 2014), partly because species vary in their contributions to different functions (Isbell et al. 2011; Meyer et al. 2018). Empirical evidence comes from both experimental and observational studies (Duffy et al. 2017), and indicates that complementarity effects mainly explain the positive effects of biodiversity on 
ecosystem functions (Loreau \& Hector 2001; Reich et al. 2012). For example, plant communities with higher diversity are able to capture more resources due to dissimilar resource use strategies, convert them into new biomass, and store more carbon (Hooper et al. 2005; Cardinale et al. 2011; Carol et al. 2018). Indeed, recent studies indicate that effects of environmental change and human disturbances are mediated by changes in biodiversity (Isbell et al. 2013; Allan et al. 2015; Dainese et al. 2019; Beaumelle et al. 2020). However, the relative importance of different, co-occurring environmental change drivers in driving biodiversity-mediated changes in ecosystem functioning and their potential context-dependencies have rarely been studied (Eisenhauer et al. 2019; Giling et al.2019). Biodiversity effects may depend on the environmental context and stress (Guerrero-Ramírez et al. 2017; Ratcliffe et al.2017), driving the balance between competitive and facilitative interactions (Wright et al. 2017).

Aridity is the most important abiotic factor influencing many grassland ecosystems, because most grasslands are water limited (Knapp \& Smith 2001; Merbold et al. 2009; Harpole et al. 2011). The projected increases in aridity will diminish the ability of global grasslands to provide life-supporting ecosystem services (Dai 2013; Sherwood \& Fu 2014; Trenberth et al. 2014; Berdugo et al.2020). Aridity has been reported to reduce plant species richness and productivity, and alter the structure of above- and belowground communities from local to global scales (Tilman \& EI Haddi 1992; Zhao \& Running 2010; Maestre et al. 2015; Berdugo et al.2020). Because ecosystem functions, such as nitrogen cycling, carbon sequestration, and litter decomposition, are regulated by these biotic attributes, ecosystem functioning is likely to decline with increasing aridity (Maestre et al. 2012; Delgado-Baquerizo et al.2013; Berdugo et al. 2017; Durán et al. 2018; Beaumelleet al. 2020). Furthermore, land-use strategies have been found to modulate the response of grasslands to climate change (Jonas et al. 2015; Karlowsky et al. 2018; Stampfli et al. 2018). Yet, how land-use and aridity interactively affect grassland biodiversity and ecosystem functioning has been rarely explored, particularly so at large spatial scales.

Livestock grazing and haying are prevalent land-use types in global grasslands, and occur across virtually all biomes from arid to wet climates (Asner et al. 2004; Steinfeld et al. 2006; Erbet al. 2017). The growing human population and mounting food demands require an increase of livestock production (Bouwman et al. 2005; Tilman et al. 2011), which will likely lead to higher grazing and haying intensity in natural grasslands. Grazing, especially by native ungulates, and haying have been reported to facilitate plant diversity and productivity and increase soil carbon (C) and nitrogen (N) stocks (Sirotnak \& Huntly 2000; Socher et al. 2012; Conget al. 2014; Wang et al. 2019). However, overgrazing and intensive haying can reduce plant diversity and biomass as well as soil functions, and exacerbate grassland degradation (Eldridge et al.2016; Eldridge et al. 2017). The stocking rates and grazing intensities that plants experience under managed grazing by livestock can be extremely high relative to the levels of grazing by native ungulates that plants experienced throughout their evolutionary histories (Milchunas \& Lauenroth 1993). For example, herbivore biomass per unit primary productivity can be an order of magnitude greater in managed livestock grazing systems than in natural grazing systems (Oesterheld et al. 1992). Further, the influence of grazing on grasslands will be altered with environmental change. For instance, in arid lands, grazing is a pervasive driver of loss of soil functions (Bridges \& Oldeman 1999), resulting in reductions in soil organic C and aboveground biomass (Gallardo \& Schlesinger 1992; Asner et al.2004). In semiarid regions, grazing could lead to woody encroachment and thus to an increase in both above- and belowground carbon stocks (Eldridge et al. 2011; Anadón et al. 2014). A global meta-analysis revealed large differences in the response of $\mathrm{C}_{3^{-}}$and $\mathrm{C}_{4}$-dominated grasslands to grazing under different rainfall regimes (McSherry \& Ritchie 2013). Therefore, grazing and haying may have context-dependent effects, which is why the ecosystem consequences of land-use on grasslands need to be examined in a wide range of environments.

Here we examine how plant species richness, plant biomass, and soil C concentrations respond to a spatial gradient of aridity (ranging from 0.25 to 0.89, covering major global ecosystem thresholds; Berdugoet al . 2020) and land-use (grazing and haying) at 716 sites along an extensive environmental gradient of 2,200 $\mathrm{km}$ across China (Fig. S1). This region is one of the major sources of animal products in China and acts as a natural green barrier towards the vast cropland regions, thus having crucial ecological and economic importance (Kang et al.2007). We hypothesized that (1) aridity and land use will decrease plant diversity, 
(2) ecosystem functioning would increase with increasing plant species richness, (3) effects of aridity, grazing, and haying on ecosystem functioning would be mediated via variation in plant species richness.

\section{Material and methods}

\section{Sampling sites}

We set up a north-east to south-west grassland transect across Inner Mongolia, Jiling, and Heilongjiang provinces in northern China (Fig. S1). The transect was approximately 2,200 km long and covered latitudes from 36.1 to $50.9^{\circ} \mathrm{N}$ and longitudes from 105.6 to $126.4^{\circ} \mathrm{E}$. The climate was predominantly arid and semi-arid continental. Mean annual temperature along the transect ranged from -4.5 to $9.5^{\circ} \mathrm{C}$, and mean annual precipitation ranged from 119 to $540 \mathrm{~mm}$. The main vegetation types that were distributed from the west to east across this transect were desert steppe, typical steppe, and meadow steppe. Soil types were predominantly arid, sandy, brown loess rich in calcium, and belonged to Kastanozem soil group in the Food and Agriculture Organization (FAO) classification system.

\section{Data collection}

Over the period of the three summers (late July to early August) of 2013-2015, in total 716 field sites were surveyed across the transect (Fig. S1). The spatial geographical coordinates of each site were recorded by GPS (62 s, Garmin, USA), and the land-use type of each site was also recorded: exclosure (51 sites), grazing (461 sites), or haying (212 sites). Most of the grazing sites were under heavy grazing (which is why we are referring to 'overgrazing' in the following), but we lack the data on accurate grazing intensity. For the haying sites, the aboveground biomass is harvested once every year.

At each site, vegetation was sampled with five to eight $0.5 \mathrm{~m} \times 0.5 \mathrm{~m}$ plots (4748 plots in total), and all vascular plant species and their cover and density were recorded. The aboveground biomass was then harvested to ground level, oven-dried at $65^{\circ} \mathrm{C}$ for $48 \mathrm{~h}$, and then weighed when returned to the laboratory. Species richness was defined as the number of species in each plot, based on cover data from field investigation. Soil samples were collected from three randomly assigned quadrats at each site, and a composite sample consisting of three soil cores (3-cm diameter, 10-cm depth) was collected from each quadrat (carefully removing the surface organic materials). After field collection, soil samples were taken to the laboratory, where they were sieved, air-dried for one month, and stored for laboratory analyses. Soil organic carbon (SOC) was determined with a total organic C analyzer (vario Toc, Elementar, Germany).

The aridity index (AI, the ratio of precipitation to potential evapotranspiration) of each site was calculated using data from WorldClim, including annual mean precipitation and temperature. To facilitate the interpretation of our results, we used 1-AI as our surrogate of aridity, and this index increases with decreasing annual mean precipitation (Pearson's $r=-0.87, P<0.001$ ) and increasing annual mean temperature (Pearson's $r=$ $0.28, P<0.001)$ in our database. To examine how the relationships between species richness and ecosystem functioning change with environments, the sites were divided into four aridity gradients: $<0.5$ (231 sites), 0.5-0.6 (250 sites), 0.6-0.7 (161 sites), and >0.7 (82 sites). These classes cover major global aridity-related ecosystem thresholds (Berdugo et al. 2020).

\section{Data analysis}

Linear mixed-effects models were used to investigate the effects of aridity, grazing, haying and their interaction on plant species richness and ecosystem functions. First, we tested the response of plant species richness to the fixed effects of aridity (as a continuous, linear predictor), grazing (as a binary predictor: $0=$ no grazing or 1 = grazing), and haying (as a binary predictor: $0=$ no haying or $1=$ haying). These models included the two-way interactions between aridity and grazing or haying. None of the sites had both grazing and haying, and thus the models did not include the grazing $\times$ haying interactions. A random intercept was included for each site. The fixed effects model structure is shown in Table 1. Second, we tested the response of aboveground biomass and soil organic $\mathrm{C}$ to these same predictors, and also included plant species richness (continuous, linear predictor) and its interaction with aridity as fixed effects (see model structure in Table 1). 
The sites were classified into three land-use types (exclosure, grazing, or haying), and land-use was divided into the two factors grazing (yes or no) and haying (yes or no).

Piecewise structural equation modelling (SEM) was used to examine if aridity and land-use affect aboveground plant biomass and SOC through changes in plant species richness (Lefcheck 2016). SEM was performed with the specification of a conceptual model of hypothetical relationships, based on a priori and theoretical knowledge (Grace 2006). The initial model included the paths from aridity, grazing, and haying to plant species richness, aboveground biomass, and SOC, and from species richness to aboveground biomass and SOC. According to modification indices, the correlation between grazing and haying was added to the model. Results of linear mixed-effects models showed that there were significant interaction effects between aridity and grazing on species richness and between aridity and haying on aboveground biomass. The paths from aridity $\times$ grazing to species richness and from aridity $\times$ haying to aboveground biomass were added to the SEM model. The path from aridity $\times$ haying to aboveground biomass was not significant, and it was removed from the model. Grazing is binary $(0=$ no or $1=$ yes $)$, haying is binary $(0=$ no or $1=$ yes $)$, and the aridity $\mathrm{x}$ grazing interaction is the product of aridity and grazing. The Akaike information criterion (AIC) and Shipley's test of $d$-separation were used to evaluate the fit of the models (Grace 2006; Lefcheck 2016), and the final test of d-separation (Fisher's $C=4.51, P=0.11$ ) showed a good model fit. Response variables were $\log$ transformed to meet linear model assumptions where appropriate. Linear mixed-effects models and SEM were conducted using the "Ime" and "piecewiseSEM" packages in R 4.0.2 (R Development Core Team 2013; Lefcheck 2016; Pinheiro \& Sarkar 2016).

\section{Results}

Response of plant species richness and ecosystem functioning to aridity and land-use

Plant species richness, aboveground biomass, and SOC decreased with increasing aridity (Table 1, Figs. 1, 2). Grazing reduced plant species richness, aboveground biomass, and SOC (Fig. 2), and the negative effects on species richness and SOC were greater at dry sites (aridity $\times$ grazing interaction effect in Table 1 ). Haying increased species richness and reduced aboveground biomass, but did not affect SOC (Fig. 2). Haying had a greater negative effect on aboveground biomass at dry sites (aridity $\times$ haying interaction effect in Table 1).

Plant species richness was positively associated with aboveground biomass and SOC, and this relationship became stronger with increasing aridity (Fig. 3 and the aridity $\times$ species richness interaction effect on aboveground biomass in Table 1). The slopes of the relationships between plant species richness and aboveground biomass as well as SOC along the aridity gradients showed that species richness had a greater effect on SOC than on aboveground biomass, and both effects increased with increasing aridity.

Plant diversity-mediated effects of aridity and land-use on ecosystem functioning

Results of SEM showed that aridity and grazing had strong interactive negative effects on species richness, which led to negative effects on plant aboveground biomass and SOC (Fig. 4). Aridity directly decreased aboveground biomass and SOC, and haying directly decreased aboveground biomass, while grazing had direct negative and indirect positive effects (through increasing species richness) on aboveground biomass and SOC. Plant species richness had greater effects on SOC than on aboveground biomass.

\section{Discussion}

Relationship between plant richness and ecosystem functioning

In accordance with our hypothesis, aboveground biomass and SOC were positively associated with species richness in this study. This is consistent with previous biodiversity and ecosystem function (BEF) work (e.g. Ma et al. 2010; Maestre et al. 2012; Pasari et al. 2013; Wagg et al. 2014; Jing et al. 2015). Though there is still debate about the mechanisms by which biodiversity impacts ecosystem function (Eisenhauer et al. 2019), many studies have demonstrated that biodiversity is a major determinant of ecosystem functioning (Isbell et al. 2011; Tilman et al. 2014; Isbell et al. 2017; Seabloom et al. 2017). Moreover, there have been several studies showing that positive biodiversity effects on ecosystem functioning are particularly strong 
when multiple ecosystem functions are considered (Isbell et al. 2011; Maestre et al. 2012; Pasari et al. 2013; Jing et al. 2015; Van Der Plas et al. 2016; Fanin et al. 2018; Hautier et al.2018; Meyer et al. 2018). Our study, across an extensive aridity gradient, complements the growing BEF literature by demonstrating strong plant diversity effects on both plant biomass production and SOC (Table 1, Figs. 3 and 4). Although the present study was not designed to identify the underlying mechanisms, based on previous work we speculate that positive effects of species richness on ecosystem functions may be mediated by complementarity in the resource use and increased plant productivity, and cascading effects on multiple organisms and ecosystem processes (Pringle et al. 2007; Maestre et al. 2012; Tilman et al. 2014). Notably, in this study, plant species richness had greater effect on SOC than on aboveground biomass, underlining the significant role of plant diversity for soil carbon storage in grassland (Lange et al. 2015).

In addition, the positive relationships between plant species richness and aboveground biomass as well as SOC were stronger at more arid sites (Fig. 3). This suggests that plant diversity has stronger beneficial effects on ecosystem functioning in dry regions, supporting the hypothesis that biodiversity may be particularly important to maintain ecosystem functions under stressful environmental conditions (Callawayet al. 2002; Ratcliffe et al. 2017; Baert et al.2018). In the more humid regions, the weaker effects of species richness on ecosystem functioning may result from reduced complementarity effects (Wright et al. 2017) and increased functional redundancy at high diversity (Craven et al. 2016). These results have significant implications for land management in a changing climate, as they indicate that the preservation of plant diversity is particularly important to maintain ecosystem functioning and services in arid environments.

\section{Effects of aridity on ecosystem functioning through plant diversity}

The negative effects of aridity on ecosystem functioning were mainly mediated by a reduction in plant species richness, in this study, which was in accordance with earlier studies at local to global scales (DelgadoBaquerizo et al. 2013; Wang et al. 2014; Brookshire \& Weaver 2015; Durán et al. 2018). Global grasslands are mainly distributed in arid and semiarid regions, and water availability is the most important limiting factor for grassland structure and ecosystem functioning (Harpole et al. 2007; Merboldet al. 2009). Drought is predicted to become more severe in many places across the globe (Dai 2013; Sherwood \& Fu 2014; Trenberthet al. 2014). In arid environment, water availability is the main driver of biological activities, and thus, an increase in aridity would have substantial effects on ecosystem structure and biogeochemical cycles (Austin et al. 2004; Schwinning \& Sala 2004; Delgado-Baquerizo et al. 2013; Wang et al. 2014). The present findings indicate that adverse climatic conditions have direct and indirect negative effects on aboveground plant biomass production and SOC and that the deterioration of ecosystem functions was mostly mediated by a reduction in plant diversity. This finding suggests that the preservation of plant biodiversity can buffer decreased ecosystem functioning due to climate change.

Effects of land-use on ecosystem functioning through plant diversity

Partially consistent with our hypothesis, overgrazing reduced plant species richness and ecosystem functions, whereas haying increased species richness and reduced aboveground biomass, but had no significant effect on SOC (Fig. 2). Despite the plant's capacity for compensatory growth, overgrazing has resulted in widespread decline in biodiversity and ecosystem functioning and services in grasslands worldwide (Milchunas \& Lauenroth 1993; Díaz et al. 2007; McSherry \& Ritchie 2013; Erb et al. 2017). As a consequence, overgrazing has been reported to decrease plant species diversity, productivity, and SOC, and to alter C, N, and P pools and stoichiometry of steppe ecosystems (Gallardo \& Schlesinger 1992; Bridges \& Oldeman 1999; Asneret al. 2004; Bai et al. 2007; Bai et al. 2012). In this study, the negative effects of grazing on plant species richness, aboveground biomass, and SOC may result from overgrazing for most sites of this region (Liu \& Diamond 2005; Han et al. 2008; Yanet al. 2013), although we lack data on accurate grazing intensity for this study. The differential effects of grazing and haying can be attributed to their different influence on dominant perennial grasses in this region (Fig. S2), which is dominated by Stipasbaicalensis, S. grandis, S krylovii, Leymus chinensis etc. The hay harvest occurs every year over many years, which reduces the resource store of the perennial species for regeneration and aboveground biomass in the following growing season (Wyka 1999; Klimeš \& Klimešová 2001; Klimešová et al. 2017). In addition, haying typically occurs during a time 
of the year, when most other species have reached their peak productivity and finished seed reproduction. As a consequence, haying may particularly reduce the biomass of dominant plant species, which resulted in a decrease on aboveground plant biomass and an increase in plant species richness. The little influence of haying on other species may explain the non-significant impact on SOC.

Interactions between aridity and land-use on ecosystem functioning

In this study, we observed significant synergistic effects of aridity and overgrazing on plant species richness and SOC, as well as of aridity and haying on aboveground biomass (Table 1, Fig. 4). These findings suggest that the effects of land-use on grassland diversity and functioning can be altered by climate. Overgrazing is a pervasive driver of soil function loss (Bridges \& Oldeman 1999), resulting in reductions in SOC and aboveground biomass in arid lands, while detrimental effects may be less pronounced in semiarid lands (Eldridge et al. 2011; Anadón et al. 2014). In this study, grazing and haying effects on ecosystem functioning were greater at more arid sites than those at more humid sites. This may be due to the higher diversity and plant recovery capacity in humid environments. The present results highlight that it is more important to preserve biodiversity in arid regions to alleviate the negative effects of land-use on grassland structure and ecosystem functioning, while biodiversity may be particularly threatened in arid lands.

Although there have been several studies on effects of diversity, aridity, and land-use on grassland functioning at the global scale (Maestre et al. 2012; Delgado-Baquerizo et al. 2013; McSherry \& Ritchie 2013; Petz et al. 2014; Ruppert et al.2015), the joint and synergistic effects of these factors have not been examined at such a large scale as this study. Implications of our study can provide guidelines for mitigating the impacts of global change and improving adaptive grassland management. In the future, multi-factor experiments with grazing or haying intensities at such large scale and on the above-belowground mechanisms underlying these effects would provide a more comprehensive understanding for sustainable grassland management.

\section{Conclusions}

In this study, we found that both aboveground plant biomass and SOC increased with increasing plant species richness. Plant species richness had greater effects on SOC than on aboveground biomass. Aridity and overgrazing decreased aboveground plant biomass and SOC through decreasing plant species richness, whereas haying had less detrimental effects on ecosystem functions and enhanced plant diversity. Together, the results demonstrated that climate change and grazing mainly threaten soil carbon storage in a synergistic way via their detrimental effects on plant diversity. However, the study also shows that certain management types like haying can maintain plant diversity and soil carbon storage. Moreover, the beneficial effects of plant diversity are particularly important in arid environments. Therefore, grassland management should be adapted to ongoing global climate change.

\section{Acknowledgements}

This project was supported by the National Key Research and Development Program of China (2016YFC0500602), the National Natural Science Foundation of China (31971744, 31770520), the State Basic Research Program (2012FY111900), the Program for Introducing Talents to Universities (B16011), and the German Centre for Integrative Biodiversity Research (iDiv) Halle-Jena-Leipzig, the German Research Foundation (FZT 118), as well as by the European Research Council (ERC) under the European Union's Horizon 2020 research and innovation program (grant agreement no 677232).

\section{References}

Allan E., Manning P., Alt F., Binkenstein J., Blaser S., Blüthgen N., Böhm S., Grassein F., Hölzel N., Klaus V.H., Kleinebecker T., Morris E.K., Oelmann Y., Prati D., Renner S.C., Rillig M.C., Schaefer M., Schloter M., Schmitt B., Schöning I., Schrumpf M., Solly E., Sorkau E., Steckel J., Steffen-Dewenter I., Stempfhuber B., Tschapka M., Weiner C.N., Weisser W.W., Werner M., Westphal C., Wilcke W. \& Fischer M. (2015). Land use intensification alters ecosystem multifunctionality via loss of biodiversity and changes to functional composition. Ecology Letters, 18, 834-843. 
Anadón J.D., Sala O.E., Turner Ii B.L. \& Bennett E.M. (2014). Effect of woody-plant encroachment on livestock production in North and South America. Proceedings of the National Academy of Sciences of the United States of America, 111, 12948-12953.

Asner G.P., Elmore A.J., Olander L.P., Martin R.E. \& Harris T. (2004). Grazing systems, ecosystem responses, and global change. Annual Review of Environment and Resources , 29, 261-299.

Austin A.T., Yahdjian L., Stark J.M., Belnap J., Porporato A., Norton U., Ravetta D.A. \& Schaeffer S.M. (2004). Water pulses and biogeochemical cycles in arid and semiarid ecosystems. Oecologia , 141, 221-235.

Baert J.M., Eisenhauer N., Janssen C.R. \& De Laender F. (2018). Biodiversity effects on ecosystem functioning respond unimodally to environmental stress. Ecology Letters , 21, 1191-1199.

Bai Y., Wu J., Clark C.M., Pan Q., Zhang L., Chen S., Wang Q. \& Han X. (2012). Grazing alters ecosystem functioning and C:N:P stoichiometry of grasslands along a regional precipitation gradient. Journal of Applied Ecology , 49, 1204-1215.

Bai Y., Wu J., Pan Q., Huang J., Wang Q., Li F., Buyantuyev A. \& Han X. (2007). Positive linear relationship between productivity and diversity: Evidence from the Eurasian Steppe.Journal of Applied Ecology , 44, 1023-1034.

Barnosky A.D., Hadly E.A., Bascompte J., Berlow E.L., Brown J.H., Fortelius M., Getz W.M., Harte J., Hastings A., Marquet P.A., Martinez N.D., Mooers A., Roopnarine P., Vermeij G., Williams J.W., Gillespie R., Kitzes J., Marshall C., Matzke N., Mindell D.P., Revilla E. \& Smith A.B. (2012). Approaching a state shift in Earth's biosphere. Nature , 486, 52-58.

Beaumelle L., De Laender F. \& Eisenhauer N. (2020). Biodiversity mediates the effects of stressors but not nutrients on litter decomposition. bioRxiv , 10.7554/eLife.55659.

Berdugo M., Delgado-Baquerizo M., Soliveres S., Hernández-Clemente R., Zhao Y., Gaitán J.J., Gross N., Saiz H., Maire V., Lehman A., Rillig M.C., Solé R.V. \& Maestre F.T. (2020). Global ecosystem thresholds driven by aridity. Science, 367, 787-790.

Berdugo M., Kéfi S., Soliveres S. \& Maestre F.T. (2017). Plant spatial patterns identify alternative ecosystem multifunctionality states in global drylands. Nature Ecology and Evolution , 1, 0003.

Bouwman A.F., Van Der Hoek K.W., Eickhout B. \& Soenario I. (2005). Exploring changes in world ruminant production systems. Agricultural Systems , 84, 121-153.

Bridges E.M. \& Oldeman L.R. (1999). Global assessment of human-induced soil degradation. Arid Soil Research and Rehabilitation, 13, 319-325.

Brookshire E.N.J. \& Weaver T. (2015). Long-term decline in grassland productivity driven by increasing dryness. Nature Communications , 6, 7148.

Brose U. \& Hillebrand H. (2016). Biodiversity and ecosystem functioning in dynamic landscapes. Philosophical Transactions of the Royal Society B: Biological Sciences , 371, 1-54.

Callaway R.M., Brooker R.W., Choler P., Kikvidze Z., Lortie C.J., Michalet R., Paolini L., Pugnaire F.I., Newingham B., Aschehoug E.T., Armas C., Kikodze D. \& Cook B.J. (2002). Positive interactions among alpine plants increase with stress. Nature , 417, 844-848.

Cardinale B.J., Duffy J.E., Gonzalez A., Hooper D.U., Perrings C., Venail P., Narwani A., MacE G.M., Tilman D., Wardle D.A., Kinzig A.P., Daily G.C., Loreau M., Grace J.B., Larigauderie A., Srivastava D.S. \& Naeem S. (2012). Biodiversity loss and its impact on humanity. Nature , 486, 59-67.

Cardinale B.J., Matulich K.L., Hooper D.U., Byrnes J.E., Duffy E., Gamfeldt L., Balvanera P., O'Connor M.I. \& Gonzalez A. (2011). The functional role of producer diversity in ecosystems. American Journal of Botany , 98, 572-592. 
Carol A.E., Hooper D.U., Paquette A. \& Hungate B.A. (2018). Ecosystem context illuminates conflicting roles of plant diversity in carbon storage. Ecology letters .

Cong W.F., van Ruijven J., Mommer L., De Deyn G.B., Berendse F. \& Hoffland E. (2014). Plant species richness promotes soil carbon and nitrogen stocks in grasslands without legumes. Journal of Ecology , 102, 1163-1170.

Craven D., Isbell F., Manning P., Connolly J., Bruelheide H., Ebeling A., Roscher C., van Ruijven J., Weigelt A., Wilsey B., Beierkuhnlein C., de Luca E., Griffin J.N., Hautier Y., Hector A., Jentsch A., Kreyling J., Lanta V., Loreau M., Meyer S.T., Mori A.S., Naeem S., Palmborg C., Wayne Polley H., Reich P.B., Schmid B., Siebenkäs A., Seabloom E., Thakur M.P., Tilman D., Vogel A. \& Eisenhauer N. (2016). Plant diversity effects on grassland productivity are robust to both nutrient enrichment and drought.Philosophical Transactions of the Royal Society B: Biological Sciences , 371, 20150277.

Díaz S., Lavorel S., McIntyre S., Falczuk V., Casanoves F., Milchunas D.G., Skarpe C., Rusch G., Sternberg M., Noy-Meir I., Landsberg J., Zhang W., Clark H. \& Campbell B.D. (2007). Plant trait responses to grazing - A global synthesis. Global Change Biology , 13, 313-341.

Díaz S., Settele J., Brondízio E.S., Ngo H.T., Agard J., Arneth A., Balvanera P., Brauman K.A., Butchart S.H.M., Chan K.M.A., Lucas A.G., Ichii K., Liu J., Subramanian S.M., Midgley G.F., Miloslavich P., Molnár Z., Obura D., Pfaff A., Polasky S., Purvis A., Razzaque J., Reyers B., Chowdhury R.R., Shin Y.J., VisserenHamakers I., Willis K.J. \& Zayas C.N. (2019). Pervasive human-driven decline of life on Earth points to the need for transformative change. Science, 366.

Dai A. (2013). Increasing drought under global warming in observations and models. Nature Climate Change , 3, 52-58.

Dainese M., Martin E.A., Aizen M.A., Albrecht M., Bartomeus I., Bommarco R., Carvalheiro L.G., ChaplinKramer R., Gagic V., Garibaldi L.A., Ghazoul J., Grab H., Jonsson M., Karp D.S., Kennedy C.M., Kleijn D., Kremen C., Landis D.A., Letourneau D.K., Marini L., Poveda K., Rader R., Smith H.G., Tscharntke T., Andersson G.K.S., Badenhausser I., Baensch S., Bezerra A.D.M., Bianchi F.J.J.A., Boreux V., Bretagnolle V., Caballero-Lopez B., Cavigliasso P., Ćetković A., Chacoff N.P., Classen A., Cusser S., Da Silva E Silva F.D., Arjen De Groot G., Dudenhöffer J.H., Ekroos J., Fijen T., Franck P., Freitas B.M., Garratt M.P.D., Gratton C., Hipólito J., Holzschuh A., Hunt L., Iverson A.L., Jha S., Keasar T., Kim T.N., Kishinevsky M., Klatt B.K., Klein A.M., Krewenka K.M., Krishnan S., Larsen A.E., Lavigne C., Liere H., Maas B., Mallinger R.E., Pachon E.M., Martínez-Salinas A., Meehan T.D., Mitchell M.G.E., Molina G.A.R., Nesper M., Nilsson L., O'Rourke M.E., Peters M.K., Plećaš M., Potts S.G., Ramos D.D.L., Rosenheim J.A., Rundlöf M., Rusch A., Sáez A., Scheper J., Schleuning M., Schmack J.M., Sciligo A.R., Seymour C., Stanley D.A., Stewart R., Stout J.C., Sutter L., Takada M.B., Taki H., Tamburini G., Tschumi M., Viana B.F., Westphal C., Willcox B.K., Wratten S.D., Yoshioka A., Zaragoza-Trello C., Zhang W., Zou Y. \& Steffan-Dewenter I. (2019). A global synthesis reveals biodiversity-mediated benefits for crop production. Science Advances , 5, eaax0121.

Delgado-Baquerizo M., Maestre F.T., Gallardo A., Bowker M.A., Wallenstein M.D., Quero J.L., Ochoa V., Gozalo B., García-Gómez M., Soliveres S., García-Palacios P., Berdugo M., Valencia E., Escolar C., Arredondo T., Barraza-Zepeda C., Bran D., Carreira J.A., Chaieb M., Conceicao A.A., Derak M., Eldridge D.J., Escudero A., Espinosa C.I., Gaitán J., Gatica M.G., Gómez-González S., Guzman E., Gutiérrez J.R., Florentino A., Hepper E., Hernández R.M., Huber-Sannwald E., Jankju M., Liu J., Mau R.L., Miriti M., Monerris J., Naseri K., Noumi Z., Polo V., Prina A., Pucheta E., Ramírez E., Ramírez-Collantes D.A., Romao R., Tighe M., Torres D., Torres-Díaz C., D. Ungar E., Val J., Wamiti W., Wang D. \& Zaady E. (2013). Decoupling of soil nutrient cycles as a function of aridity in global drylands.Nature , 502, 672-676.

Duffy E., J., Godwin C.M. \& Cardinale B.J. (2017). Biodiversity effects in the wild are common and as strong as key drivers of productivity. Nature, 549, 261-264.

Durán J., Delgado-Baquerizo M., Dougill A.J., Guuroh R.T., Linstädter A., Thomas A.D. \& Maestre F.T. (2018). Temperature and aridity regulate spatial variability of soil multifunctionality in drylands across the 
globe. Ecology, 99, 1184-1193.

Eisenhauer N., Schielzeth H., Barnes A.D., Barry K.E., Bonn A., Brose U., Bruelheide H., Buchmann N., Buscot F. \& Ebeling A. (2019). Chapter One - A multitrophic perspective on biodiversity-ecosystem functioning research. Advances in Ecological Research, 1-54.

Eldridge D.J., Bowker M.A., Maestre F.T., Roger E., Reynolds J.F. \& Whitford W.G. (2011). Impacts of shrub encroachment on ecosystem structure and functioning: Towards a global synthesis. Ecology Letters , 14, 709-722.

Eldridge D.J., Delgado-Baquerizo M., Travers S.K., Val J., Oliver I., Hamonts K. \& Singh B.K. (2017). Competition drives the response of soil microbial diversity to increased grazing by vertebrate herbivores. Ecology , 98, 1922-1931.

Eldridge D.J., Poore A.G.B., Ruiz-Colmenero M., Letnic M. \& Soliveres S. (2016). Ecosystem structure, function, and composition in rangelands are negatively affected by livestock grazing. Ecological Applications , 26, 1273-1283.

Erb K.H., Luyssaert S., Meyfroidt P., Pongratz J., Don A., Kloster S., Kuemmerle T., Fetzel T., Fuchs R., Herold M., Haberl H., Jones C.D., Marín-Spiotta E., McCallum I., Robertson E., Seufert V., Fritz S., Valade A., Wiltshire A. \& Dolman A.J. (2017). Land management: data availability and process understanding for global change studies. Global Change Biology , 23, 512-533.

Fanin N., Gundale M.J., Farrell M., Ciobanu M., Baldock J.A., Nilsson M.C., Kardol P. \& Wardle D.A. (2018). Consistent effects of biodiversity loss on multifunctionality across contrasting ecosystems. Nature Ecology and Evolution , 2, 269-278.

Gallardo A. \& Schlesinger W.H. (1992). Carbon and nitrogen limitations of soil microbial biomass in desert ecosystems. Biogeochemistry, 18, 1-17.

Giling D.P., Beaumelle L., Phillips H.R.P., Cesarz S., Eisenhauer N., Ferlian O., Gottschall F., Guerra C., Hines J., Sendek A., Siebert J., Thakur M.P. \& Barnes A.D. (2019). A niche for ecosystem multifunctionality in global change research. Global Change Biology, 25, 763-774.

Grace J.B. (2006). Structural equation modeling and natural systems . Cambridge University Press, New York, NY, USA.

Guerrero-Ramírez N.R., Craven D., Reich P.B., Ewel J.J., Isbell F., Koricheva J., Parrotta J.A., Auge H., Erickson H.E., Forrester D.I., Hector A., Joshi J., Montagnini F., Palmborg C., Piotto D., Potvin C., Roscher C., Van Ruijven J., Tilman D., Wilsey B. \& Eisenhauer N. (2017). Diversity-dependent temporal divergence of ecosystem functioning in experimental ecosystems. Nature Ecology and Evolution , 1, 1639-1642.

Han J.G., Zhang Y.J., Wang C.J., Bai W.M., Wang Y.R., Han G.D. \& Li L.H. (2008). Rangeland degradation and restoration management in China. Rangeland Journal , 30, 233-239.

Harpole W.S., Ngai J.T., Cleland E.E., Seabloom E.W., Borer E.T., Bracken M.E., Elser J.J., Gruner D.S., Hillebrand H., Shurin J.B. \& Smith J.E. (2011). Nutrient co-limitation of primary producer communities. Ecology Letters , 14, 852-862.

Harpole W.S., Potts D.L. \& Suding K.N. (2007). Ecosystem responses to water and nitrogen amendment in a California grassland. Global Change Biology, 13, 2341-2348.

Hautier Y., Isbell F., Borer E.T., Seabloom E.W., Harpole W.S., Lind E.M., MacDougall A.S., Stevens C.J., Adler P.B., Alberti J., Bakker J.D., Brudvig L.A., Buckley Y.M., Cadotte M., Caldeira M.C., Chaneton E.J., Chu C., Daleo P., Dickman C.R., Dwyer J.M., Eskelinen A., Fay P.A., Firn J., Hagenah N., Hillebrand H., Iribarne O., Kirkman K.P., Knops J.M.H., La Pierre K.J., McCulley R.L., Morgan J.W., Pärtel M., Pascual J., Price J.N., Prober S.M., Risch A.C., Sankaran M., Schuetz M., Standish R.J., Virtanen R., Wardle G.M., 
Yahdjian L. \& Hector A. (2018). Local loss and spatial homogenization of plant diversity reduce ecosystem multifunctionality. Nature Ecology and Evolution , 2, 50-56.

Hoekstra J.M., Boucher T.M., Ricketts T.H. \& Roberts C. (2005). Confronting a biome crisis: Global disparities of habitat loss and protection. Ecology Letters , 8, 23-29.

Hooper D.U., Chapin Iii F.S., Ewel J.J., Hector A., Inchausti P., Lavorel S., Lawton J.H., Lodge D.M., Loreau M., Naeem S., Schmid B., Setälä H., Symstad A.J., Vandermeer J. \& Wardle D.A. (2005). Effects of biodiversity on ecosystem functioning: A consensus of current knowledge. Ecological Monographs , 75, 3-35.

Isbell F., Calcagno V., Hector A., Connolly J., Harpole W.S., Reich P.B., Scherer-Lorenzen M., Schmid B., Tilman D., Van Ruijven J., Weigelt A., Wilsey B.J., Zavaleta E.S. \& Loreau M. (2011). High plant diversity is needed to maintain ecosystem services. Nature , 477, 199-202.

Isbell F., Gonzalez A., Loreau M., Cowles J., Díaz S., Hector A., MacE G.M., Wardle D.A., O'Connor M.I., Duffy J.E., Turnbull L.A., Thompson P.L. \& Larigauderie A. (2017). Linking the influence and dependence of people on biodiversity across scales. Nature, 546, 65-72.

Isbell F., Reich P.B., Tilman D., Hobbie S.E., Polasky S. \& Binder S. (2013). Nutrient enrichment, biodiversity loss, and consequent declines in ecosystem productivity.Proceedings of the National Academy of Sciences of the United States of America, 110, 11911-11916.

Jing X., Sanders N.J., Shi Y., Chu H., Classen A.T., Zhao K., Chen L., Shi Y., Jiang Y. \& He J.S. (2015). The links between ecosystem multifunctionality and above-and belowground biodiversity are mediated by climate. Nature Communications , 6, 8159-8159.

Jonas J.L., Buhl D.A. \& Symstad A.J. (2015). Impacts of weather on long-term patterns of plant richness and diversity vary with location and management. Ecology, 96, 2417-2432.

Kang L., Han X., Zhang Z. \& Sun O.J. (2007). Grassland ecosystems in China: Review of current knowledge and research advancement. Philosophical Transactions of the Royal Society B: Biological Sciences , 362, 997-1008.

Karlowsky S., Augusti A., Ingrisch J., Hasibeder R., Lange M., Lavorel S., Bahn M. \& Gleixner G. (2018). Land use in mountain grasslands alters drought response and recovery of carbon allocation and plantmicrobial interactions. Journal of Ecology , 106, 1230-1243.

Klimeš L. \& Klimešová J. (2001). The effects of mowing and fertilization on carbohydrate reserves and regrowth of grasses: Do they promote plant coexistence in species-rich meadows? Evolutionary Ecology , 15, 363-382.

Klimešová J., Janeček S., Bartušková A., Bartoš M., Altman J., Doležal J., Lanta V. \& Latzel V. (2017). Is the scaling relationship between carbohydrate storage and leaf biomass in meadow plants affected by the disturbance regime? Annals of Botany, 120, 979-985.

Knapp A.K. \& Smith M.D. (2001). Variation among biomes in temporal dynamics of aboveground primary production. Science, 291, 481-484.

Lange M., Eisenhauer N., Sierra C.A., Bessler H., Engels C., Griffiths R.I., Mellado-Vázquez P.G., Malik A.A., Roy J., Scheu S., Steinbeiss S., Thomson B.C., Trumbore S.E. \& Gleixner G. (2015). Plant diversity increases soil microbial activity and soil carbon storage. Nature Communications , 6, 6707.

Lefcheck J.S. (2016). piecewiseSEM: Piecewise structural equation modelling in $\mathrm{r}$ for ecology, evolution, and systematics. Methods in Ecology and Evolution , 7, 573-579.

Liu J. \& Diamond J. (2005). China's environment in a globalizing world. Nature, 435, 1179-1186.

Loreau M. \& Hector A. (2001). Partitioning selection and complementarity in biodiversity experiments.Nature , 412, 72-76. 
Ma W., He J.S., Yang Y., Wang X., Liang C., Anwar M., Zeng H., Fang J. \& Schmid B. (2010). Environmental factors covary with plant diversity-productivity relationships among Chinese grassland sites. Global Ecology and Biogeography , 19, 233-243.

Maestre F.T., Delgado-Baquerizo M., Jeffries T.C., Eldridge D.J., Ochoa V., Gozalo B., Quero J.L., GarcíaGómez M., Gallardo A., Ulrich W., Bowker M.A., Arredondo T., Barraza-Zepeda C., Bran D., Florentino A., Gaitán J., Gutiérrez J.R., Huber-Sannwald E., Jankju M., Mau R.L., Miriti M., Naseri K., Ospina A., Stavi I., Wang D., Woods N.N., Yuan X., Zaady E. \& Singh B.K. (2015). Increasing aridity reduces soil microbial diversity and abundance in global drylands. Proceedings of the National Academy of Sciences of the United States of America, 112, 15684-15689.

Maestre F.T., Quero J.L., Gotelli N.J., Escudero A., Ochoa V., Delgado-Baquerizo M., García-Gómez M., Bowker M.A., Soliveres S., Escolar C., García-Palacios P., Berdugo M., Valencia E., Gozalo B., Gallardo A., Aguilera L., Arredondo T., Blones J., Boeken B., Bran D., Conceição A.A., Cabrera O., Chaieb M., Derak M., Eldridge D.J., Espinosa C.I., Florentino A., Gaitán J., Gabriel Gatica M., Ghiloufi W., Gómez-González S., Gutiérrez J.R., Hernández R.M., Huang X., Huber-Sannwald E., Jankju M., Miriti M., Monerris J., Mau R.L., Morici E., Naseri K., Ospina A., Polo V., Prina A., Pucheta E., Ramírez-Collantes D.A., Romão R., Tighe M., Torres-Díaz C., Val J., Veiga J.P., Wang D. \& Zaady E. (2012). Plant species richness and ecosystem multifunctionality in global drylands. Science, 335, 214-218.

McSherry M.E. \& Ritchie M.E. (2013). Effects of grazing on grassland soil carbon: A global review. Global Change Biology , 19, 1347-1357.

Merbold L., Ardö J., Arneth A., Scholes R.J., Nouvellon Y., De Grandcourt A., Archibald S., Bonnefond J.M., Boulain N., Brueggemann N., Bruemmer C., Cappelaere B., Ceschia E., El-Khidir H.A.M., El-Tahir B.A., Falk U., Lloyd J., Kergoat L., Le Dantec V., Mougin E., Muchinda M., Mukelabai M.M., Ramier D., Roupsard O., Timouk F., Veenendaal E.M. \& Kutsch W.L. (2009). Precipitation as driver of carbon fluxes in 11 African ecosystems. Biogeosciences , 6, 1027-1041.

Meyer S.T., Ptacnik R., Hillebrand H., Bessler H., Buchmann N., Ebeling A., Eisenhauer N., Engels C., Fischer M., Halle S., Klein A.M., Oelmann Y., Roscher C., Rottstock T., Scherber C., Scheu S., Schmid B., Schulze E.D., Temperton V.M., Tscharntke T., Voigt W., Weigelt A., Wilcke W. \& Weisser W.W. (2018). Biodiversity-multifunctionality relationships depend on identity and number of measured functions. Nature Ecology and Evolution, 2, 44-49.

Milchunas D.G. \& Lauenroth W.K. (1993). Quantitative effects of grazing on vegetation and soils over a global range of environments. Ecological Monographs , 63, 327-366.

Millenium Ecosystem Assessment. (2005). Ecosystems and Human Well-Being, Volume I: Current States and Trends. Island Press, Washington, D.C.

O'Mara F.P. (2012). The role of grasslands in food security and climate change. Annals of Botany , 110, 1263-1270.

Oesterheld M., Sala O.E. \& McNaughton S.J. (1992). Effect of animal husbandry on herbivore-carrying capacity at a regional scale. Nature , 356, 234-236.

Pasari J.R., Levi T., Zavaleta E.S. \& Tilman D. (2013). Several scales of biodiversity affect ecosystem multifunctionality. Proceedings of the National Academy of Sciences of the United States of America, 110, 10219-10222.

Petz K., Alkemade R., Bakkenes M., Schulp C.J.E., van der Velde M. \& Leemans R. (2014). Mapping and modelling trade-offs and synergies between grazing intensity and ecosystem services in rangelands using global-scale datasets and models. Global Environmental Change, 29, 223-234.

Pinheiro J. \& Sarkar D. (2016). Package nlme: linear and nonlinear mixed effects models. Version 3.1-127. https://cran.r-project.org/web/packages/nlme/index.html . 
Pringle R.M., Young T.P., Rubenstein D.I. \& McCauley D.J. (2007). Herbivore-initiated interaction cascades and their modulation by productivity in an African savanna.Proceedings of the National Academy of Sciences of the United States of America, 104, 193-197.

R Development Core Team. (2013). R: A language and environment for statistical computing. R Foundation for Statistical Computing, Vienna, Austria. URL http://www.R-project.org/.

Ratcliffe S., Wirth C., Jucker T., van der Plas F., Scherer-Lorenzen M., Verheyen K., Allan E., Benavides R., Bruelheide H., Ohse B., Paquette A., Ampoorter E., Bastias C.C., Bauhus J., Bonal D., Bouriaud O., Bussotti F., Carnol M., Castagneyrol B., Chećko E., Dawud S.M., Wandeler H.D., Domisch T., Finér L., Fischer M., Fotelli M., Gessler A., Granier A., Grossiord C., Guyot V., Haase J., Hättenschwiler S., Jactel H., Jaroszewicz B., Joly F.X., Kambach S., Kolb S., Koricheva J., Liebersgesell M., Milligan H., Müller S., Muys B., Nguyen D., Nock C., Pollastrini M., Purschke O., Radoglou K., Raulund-Rasmussen K., Roger F., Ruiz-Benito P., Seidl R., Selvi F., Seiferling I., Stenlid J., Valladares F., Vesterdal L. \& Baeten L. (2017). Biodiversity and ecosystem functioning relations in European forests depend on environmental context. Ecology Letters , 20, 1414-1426.

Reich P.B., Tilman D., Isbell F., Mueller K., Hobbie S.E., Flynn D.F.B. \& Eisenhauer N. (2012). Impacts of biodiversity loss escalate through time as redundancy fades.Science, 336, 589-592.

Ruppert J.C., Harmoney K., Henkin Z., Snyman H.A., Sternberg M., Willms W. \& Linstädter A. (2015). Quantifying drylands' drought resistance and recovery: The importance of drought intensity, dominant life history and grazing regime. Global Change Biology , 21, 1258-1270.

Schwinning S. \& Sala O.E. (2004). Hierarchy of responses to resource pulses in arid and semi-arid ecosystems. Oecologia , 141, 211-220.

Seabloom E.W., Kinkel L., Borer E.T., Hautier Y., Montgomery R.A. \& Tilman D. (2017). Food webs obscure the strength of plant diversity effects on primary productivity.Ecology Letters , 20, 505-512.

Sherwood S. \& Fu Q. (2014). A drier future? Science, 343, 737-739.

Siebert J., Thakur M.P., Reitz T., Schädler M., Schulz E., Yin R., Weigelt A. \& Eisenhauer N. (2019). Extensive grassland-use sustains high levels of soil biological activity, but does not alleviate detrimental climate change effects. In:Advances in Ecological Research, pp. 25-58.

Sirotnak J.M. \& Huntly N.J. (2000). Direct and indirect effects of herbivores on nitrogen dynamics: Voles in riparian areas. Ecology, 81, 78-87.

Socher S.A., Prati D., Boch S., Müller J., Klaus V.H., Hölzel N. \& Fischer M. (2012). Direct and productivitymediated indirect effects of fertilization, mowing and grazing on grassland species richness. Journal of Ecology , 100, 1391-1399.

Stampfli A., Bloor J.M.G., Fischer M. \& Zeiter M. (2018). High land-use intensity exacerbates shifts in grassland vegetation composition after severe experimental drought. Global Change Biology , 24, 2021-2034.

Steinfeld H., Gerber P., Wassenaar T., Castel V., Rosales M. \& De Haan C. (2006). Livestock's Long Shadow: Environmental Issues and Options. FAO.

Tilman D., Balzer C., Hill J. \& Befort B.L. (2011). Global food demand and the sustainable intensification of agriculture. Proceedings of the National Academy of Sciences of the United States of America, 108, 20260-20264.

Tilman D. \& EI Haddi A. (1992). Drought and biodiversity in Grasslands. Oecologia, 89, 257-264.

Tilman D., Isbell F. \& Cowles J.M. (2014). Biodiversity and ecosystem functioning. Annual Review of Ecology, Evolution, and Systematics , 45, 471-493. 
Trenberth K.E., Dai A., Van Der Schrier G., Jones P.D., Barichivich J., Briffa K.R. \& Sheffield J. (2014). Global warming and changes in drought. Nature Climate Change, 4, 17-22.

Van Der Plas F., Manning P., Allan E., Scherer-Lorenzen M., Verheyen K., Wirth C., Zavala M.A., Hector A., Ampoorter E., Baeten L., Barbaro L., Bauhus J., Benavides R., Benneter A., Berthold F., Bonal D., Bouriaud O., Bruelheide H., Bussotti F., Carnol M., Castagneyrol B., Charbonnier Y., Coomes D., Coppi A., Bastias C.C., Muhie Dawud S., De Wandeler H., Domisch T., Finér L., Gessler A., Granier A., Grossiord C., Guyot V., Hättenschwiler S., Jactel H., Jaroszewicz B., Joly F.X., Jucker T., Koricheva J., Milligan H., Müller S., Muys B., Nguyen D., Pollastrini M., Raulund-Rasmussen K., Selvi F., Stenlid J., Valladares F., Vesterdal L., Zielínski D. \& Fischer M. (2016). Jack-of-all-trades effects drive biodiversity-ecosystem multifunctionality relationships in European forests. Nature Communications , 7, 11109-11109.

Wagg C., Bender S.F., Widmer F. \& Van Der Heijden M.G.A. (2014). Soil biodiversity and soil community composition determine ecosystem multifunctionality. Proceedings of the National Academy of Sciences of the United States of America, 111, 5266-5270.

Wang C., Wang X., Liu D., Wu H., Lü X., Fang Y., Cheng W., Luo W., Jiang P., Shi J., Yin H., Zhou J., Han X. \& Bai E. (2014). Aridity threshold in controlling ecosystem nitrogen cycling in arid and semi-Arid grasslands. Nature Communications , 5, 4799.

Wang L., Delgado-Baquerizo M., Wang D., Isbell F., Liu J., Feng C., Liu J., Zhong Z., Zhu H., Yuan X., Chang Q. \& Liu C. (2019). Diversifying livestock promotes multidiversity and multifunctionality in managed grasslands. Proceedings of the National Academy of Sciences of the United States of America, 116, 6187-6192.

White R., Murray S. \& Rohweder M. (2000). Pilot Analysis of Global Ecosystems (PAGE): Grassland Ecosystems . World Resources Institute, Washington, DC.

Wright A.J., Wardle D.A., Callaway R. \& Gaxiola A. (2017). The overlooked role of facilitation in biodiversity experiments. Trends in Ecology and Evolution, 32, 383-390.

Wyka T. (1999). Carbohydrate storage and use in an alpine population of the perennial herb, Oxytropis sericea. Oecologia , 120, 198-208.

Yan L., Zhou G. \& Zhang F. (2013). Effects of different Grazing intensities on grassland production in China: A meta-analysis. PLoS ONE , 8, e81466.

Zhao M. \& Running S.W. (2010). Drought-induced reduction in global terrestrial net primary production from 2000 through 2009. Science, 329, 940-943.

Table 1. Fixed effects of aridity, grazing, haying, and interactions on plant species richness and ecosystem functions for linear mixed-effects models.

\begin{tabular}{llll}
\hline & Species richness & Aboveground biomass & Soil organic C \\
\hline & $F_{1,710}$ & $F_{1,710}$ & $F_{1,709}$ \\
Aridity & $4.02^{*}$ & $60.63^{* * *}$ & 2.67 \\
Grazing & $4.98^{*}$ & 2.29 & 1.64 \\
Aridity $\times$ Grazing & $15.51^{* * *}$ & 1.68 & $5.12^{*}$ \\
Haying & 0.28 & 1.20 & 1.96 \\
Aridity $\times$ Haying & 0.56 & $6.24^{*}$ & 1.19 \\
Species richness & & $58.50^{* * *}$ & $51.05^{* * *}$ \\
Aridity $\times$ Species richness & $80.52^{* * *}$ & 0.56 \\
\hline & & \\
${ }^{*} P[?] 0.05,{ }^{* *} P[?] 0.01,{ }^{* * *} P[?] 0.001$. & &
\end{tabular}



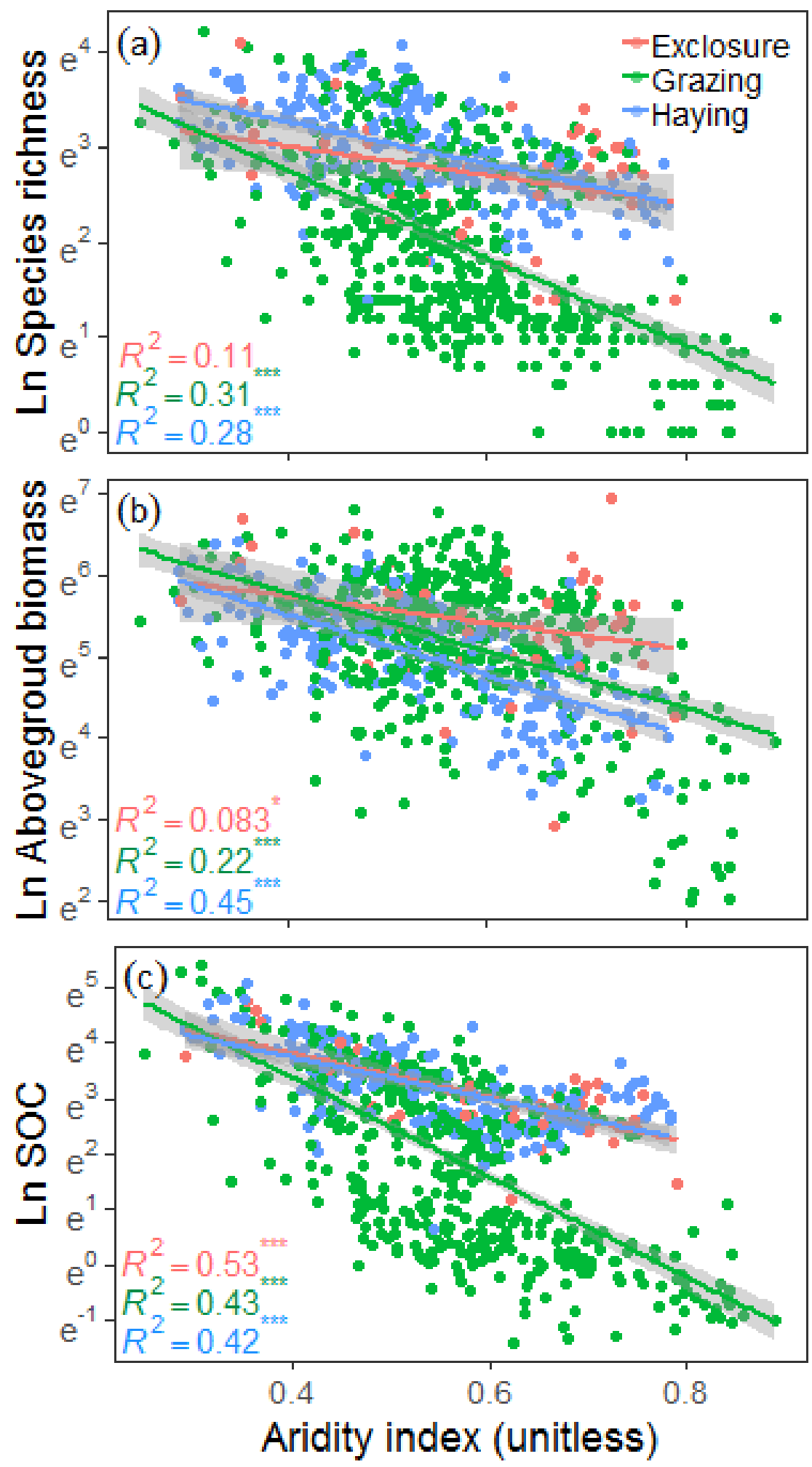
Figure 1. Relationshipes between aridity and plant species richness, aboveground plant biomass, and SOC across exclosed, grazed, and hayed sites. Relationshipes between aridity and species richness (a), aboveground biomass (b), and SOC (c). ${ }^{*} P[?] 0.05,{ }^{* *} P[?] 0.01,{ }^{* * *} P[?] 0.001$.
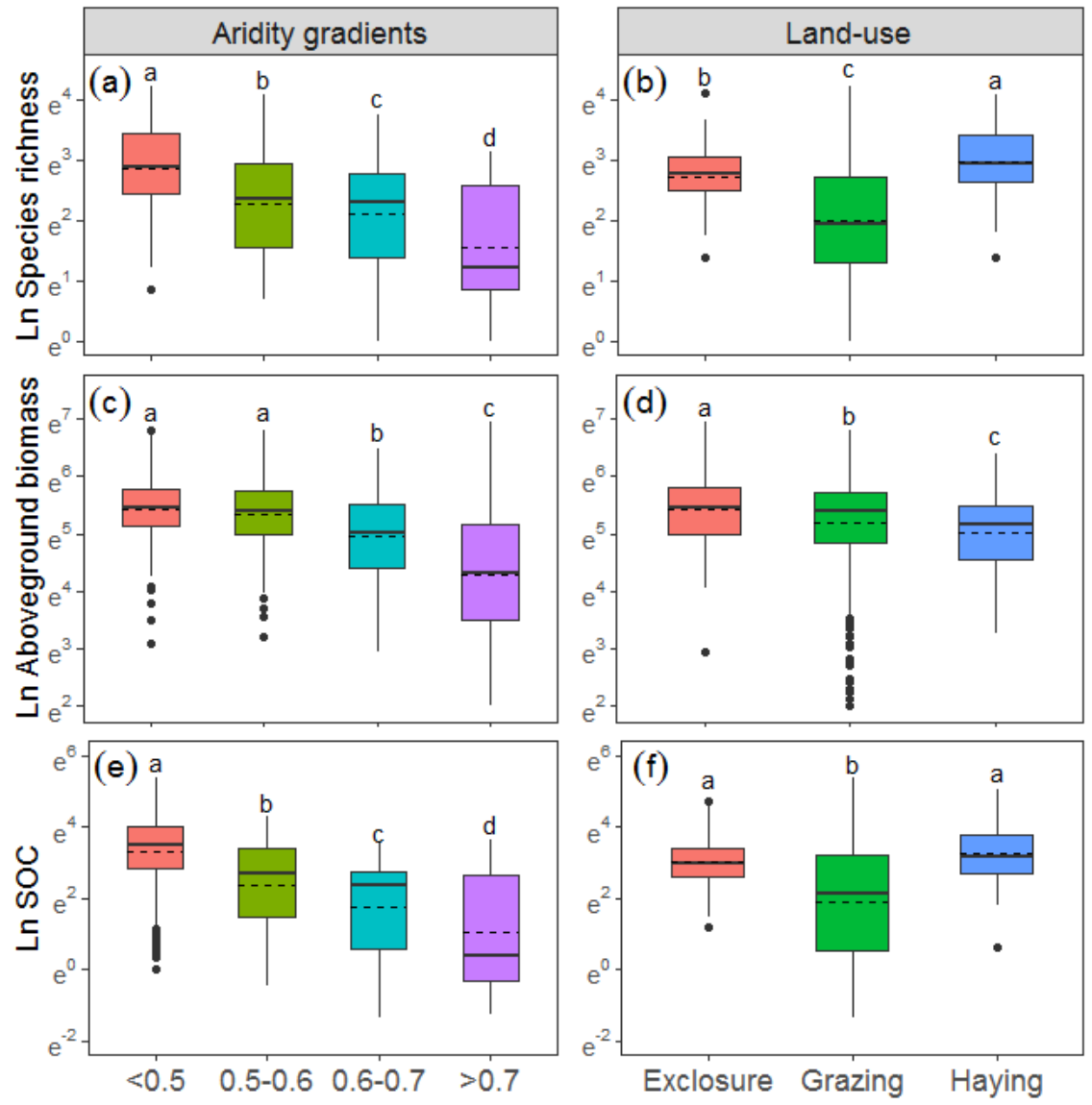

Figure 2. Boxplots showing effects of aridity (a, c, e) and land-use (b, d, f) on plant species richness, aboveground plant biomass, and SOC. Bars with varying letters (LSD test, $P<0.05$ ) differ significantly. 

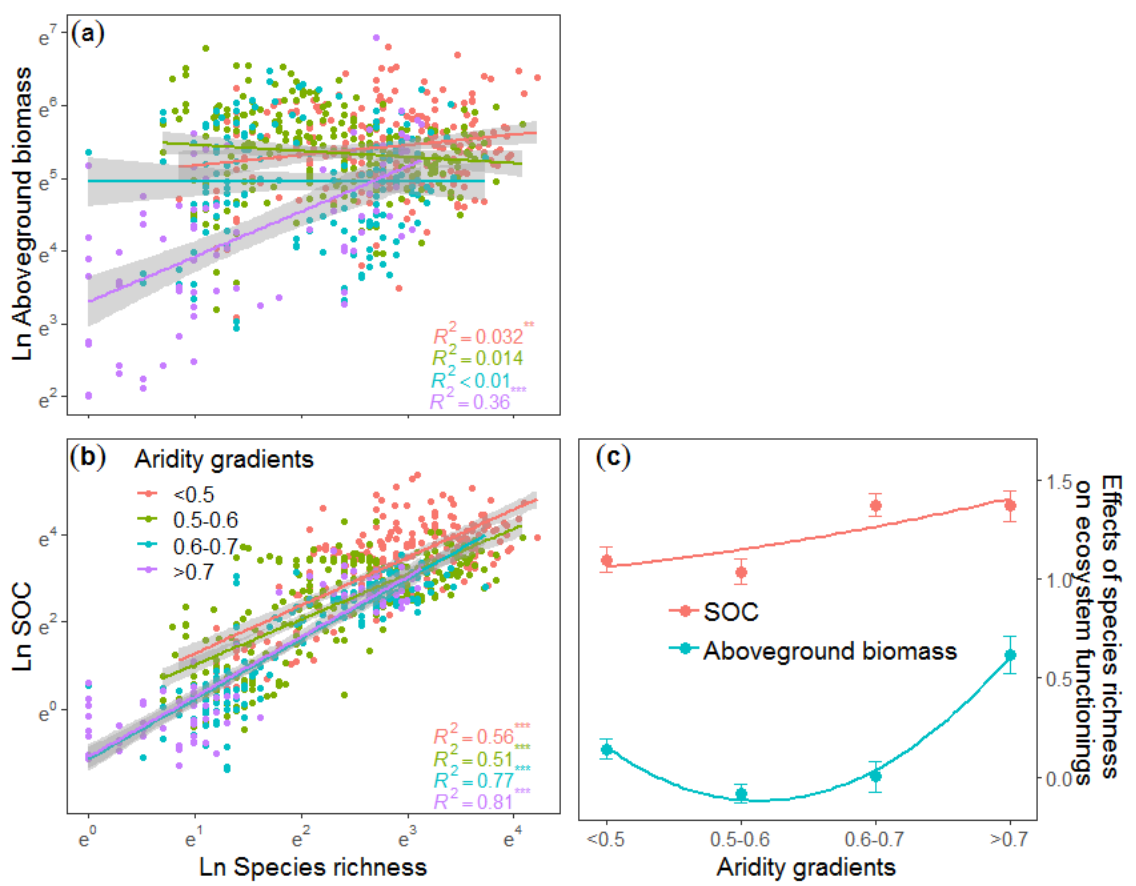

Figure 3. Effects of aridity on the relationships between plant species richness and ecosystem functioning. Relationships between plant species richness and aboveground biomass (a) and SOC (b), and effects of plant species richness on ecosystem functions (c, the slope of the relationships between plant species richness and aboveground biomass and SOC) along aridity gradients. ${ }^{*} P[?] 0.05,{ }^{* *} P[?] 0.01,{ }^{* * *} P[?] 0.001$.

\section{Hosted file}

image4.emf available at https://authorea.com/users/357827/articles/480222-aridity-and-
overgrazing-decrease-soil-carbon-storage-by-decreasing-grassland-plant-diversity

Figure 4. Structural equation model testing effects of aridity, grazing, and haying on plant species richness, abovegound plant biomass, and SOC. Blue and red solid arrows indicate positive and negative significant effects, respectively, and thickness of the colored solid arrows reflects the magnitude of the standardized path coefficients. Grey arrows indicate non-significant effects. 